\title{
Eurobond Issue And Firm Value
}

\author{
Roya K. Ardalan, Old Dominion University, USA
}

\begin{abstract}
This study explores differences between US-bonds and Eurobonds and analyzes the effect of some Eurobond characteristics on firm value. First, it attempts to determine if investors view U.S. and Eurobonds similarly, especially after the change in tax laws that exempted U.S.-bond holders from paying 30 percent withholding taxes. Then, the paper analyzes the effect of some of the Eurobond issue characteristics such as issue size, issue frequency, yield spread, and maturity term on firm value. The results show that Eurobonds provide investors an alternative for portfolio diversification, and as a result, the bond market remained segmented. Also, the increase in firm value was statistically significant for the firm's first Eurobond issue. The increase in firm value for the subsequent Eurobond issues was not statistically significant.
\end{abstract}

Keywords: Eurobonds, U.S.-bonds, Financing Strategy, Firm value

\section{INTRODUCTION}

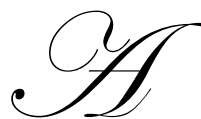

fter the tax law change of 1984 , non-U.S. investors were no longer required to pay 30 percent withholding taxes on their income from U.S.-bonds. This change put U.S.-bonds and Eurobonds on a level field with respect to taxes. Also, researchers have demonstrated that savings by companies from Eurobonds' lower interest rates are offset by their higher underwriting costs.

However, there exist some differences between U.S.-bonds and Eurobonds that may be important for some firms and investors. One difference is that ownership of U.S. securities requires registration, while Eurobonds are bearer securities and do not require registration. This is an important matter for investors who prefer to remain anonymous. Other differences include the existence of barriers in supplying Eurobonds and the structural differences in credit risk premiums among Eurobonds and U.S.-bonds. These differences may tend to keep the U.S.bond and Eurobond markets segmented.

Also, Eurobonds have been an important component of sources of funds for corporations. Hence, additional knowledge about the way their characteristics affect firm value is necessary for managers and researchers.

This paper explores the differences in the effect of issuing U.S.-bonds and Eurobonds on firm value to determine if these two markets are segmented in spite of the aforementioned 1984 U.S. tax law that removed the tax advantage of Eurobonds over U.S.-bonds. We will then examine the effect of Eurobonds' yield spread, size of the issue, frequency of issues, and maturity term on firm value to understand the policy implications of these factors in corporate structures' Eurobond offerings.

\section{THEORETICAL AND EMPIRICAL LITERATURE}

The Eurobond market has grown steadily for several reasons. Eurobonds give investors an alternative investment to U.S. dollar-denominated bonds, and allow corporations to borrow directly from investors, rather than through intermediaries. Also, there is a shift among European companies away from bank borrowing, a practice that has long been followed by U.S. companies, to issuing bonds directly to investors.

Two main forces sustain the growth of the Eurobonds (Bowe, 1988): (1.) Differences in regulatory procedures between international and domestic markets provide arbitrage opportunities, and (2.) the Eurobond 
market provides an alternative source of financing for borrowers who may have different borrowing requirements that cannot be met in the U.S. market.

The expansion and increased importance of Eurobonds have attracted the attention of researchers and practitioners. Although the body of research in Eurobonds is not as large as expected, a number of studies have been conducted to compare different aspects of Eurobonds with U.S.-bonds. Beer (1995) provides an overview of the Eurobond market and shows how the U.S. share of the market has decreased relative to Eurobonds offered by other countries. Finnerty and Nunn (1985) and Kidwell, Marr, and Thompson (1985) conclude that fixed-rate Eurobond yields are lower compared to fixed-rate domestic bonds. However, Kidwell, Marr and Thompson (1985) found that the higher cost of underwriting for Eurobonds offsets, to some extent, their interest cost savings. Mahajan and Fraser (1986) show that dollar Eurobonds and U.S.-bonds yields are similar, and their prices are not significantly influenced by the size of the issue, rating of the issuing organization, or the market's familiarity with the issuer. Steiner and Heinke (2001) indicate that a Eurobond's negative rating announcement results in the decrease in the Eurobond's price, while a positive rating announcement does not significantly increase the Eurobond's price.

Kim and Stulz (1988) state that impediments to the adjustment of Eurobonds supplies to new demand conditions result in arbitrage opportunities that firms can utilize to increase their market value. Unlike the convertible and straight U.S. debt offerings that have a negative price effect (Mikkelson \& Partch, 1986; Ekbo, 1986), the announcement of Eurobonds results in a positive abnormal return (Kim \& Stulz, 1988; Deshpande \& Philippatos, 1988) due likely to factors such as the absence of Securities and Exchange Commission regulations and fewer restrictive debt covenants. The Eurobonds issuing and contracting expenses exceed U.S.-bond expenses (Mendelson, 1980,1983) therefore, only highly reputable firms can benefit by issuing Eurobonds at a lower yield than U.S.-bonds. Kim and Stulz (1988) also show that since highly reputable U.S. firms have the ability to raise funds abroad, these firms should benefit more the first time they issue Eurobonds.

After July 1984, non-U.S. investors were no longer required by the U.S. government to pay $30 \%$ withholding taxes on their income received from the U.S.-bonds (Bowe, 1988). This change in tax laws removed the Eurobond's tax advantage over U.S.-bonds for non-U.S. investors. Kim and Stulz (1992) conducted the only study of stock price reaction to the announcement of convertible bond issue after the removal of the U.S. withholding tax on bonds held by non-U.S. investors, and concluded that the announcement effect of Eurobonds and domestic convertible bonds were similar.

An important feature of Eurobonds is that they are bearer securities. As bearer securities they are appealing to non-U.S. investors who desire anonymity. In the United States, ownership of securities requires registration. This requirement sets up a barrier to investment by non-U.S. investors, and tends to segment the U.S. and non-U.S. capital markets (Adler \& Dumas, 1983; Stulz, 1981). Listing corporations on foreign exchange is one way of reducing investment barriers for non-U.S. investors and as a result, increasing corporations' stock prices (Stapleton \& Subrahmanyam, 1977; Alexander, 1987,1988). In this respect issuing Eurobonds resembles international listing of a corporation stock and should result in an increase in firm value.

Marr, Trimble and Varma (1991) studied Euro-equity offerings and showed that new financial instruments that reduce existing barriers to investment internationally enable firms to exploit profitable opportunities abroad. Because Eurobond offerings also reduce financial barriers to investment overseas, announcement of Eurobond issues should have a positive impact on the firm value.

Investors continue to demand Eurobonds for privacy, portfolio diversification, and exchange rate risk management. In addition, there are differences in the structure of credit risk premiums in the Eurobond market (Murphy, 2003), and barriers still exist in supplying Eurobonds, which tend to keep the U.S. and Eurobond markets segmented. Therefore, we believe that in spite of the 1984 tax law change, Eurobonds and U.S.-bonds should not be equivalent. 
To test the equivalency of U.S.-bonds and Eurobonds, this paper studies the announcement effect of issuing Eurobonds by U.S. corporations on firm value using data for the period of 1987 to 1991 . This period was used to minimize any sharp influences that the U.S. tax law change might have had in the market shortly after its adoption. Also, we did not use more recent data to make sure that the data does not include the effect in the market caused by the large variety of Eurobonds products that have been introduced since that period.

Also, this paper investigates the effect of several factors that have been discussed in the literature (Amira, 2004) such as yield spread, size of the issue, frequency of issues, and maturity term on firm value. The goal is to increase our understanding of the reasons for the existence of Eurobonds' possible financing bargains and their policy implications in corporate structures' Eurobond offerings.

This paper is organized as follows: Section 3 describes the data. Section 4 presents the methodology used and the results obtained for each study. Finally, section 5 presents conclusions and summarizes the findings of this study.

\section{DATA}

The data was composed of 224 Eurobond launch dates by 56 U.S. companies. For every launch date (i.e. the first trading day overseas); the corresponding principal amount, the maturity date, and the offer yield were observed. The data was obtained from Securities Data Company. The Eurobonds used in the sample were straight debt issues. Table 1 shows the number of issues for each year along with the average principal amount, average maturity term, and average offer yield.

Table 1

Summary Data For Eurobond Offerings

\begin{tabular}{lllll}
\hline Year & $\begin{array}{l}\text { Number } \\
\text { Of Issues }\end{array}$ & $\begin{array}{l}\text { Average } \\
\text { Principle Amount } \\
\text { (\$ Million) }\end{array}$ & $\begin{array}{l}\text { Average } \\
\text { Maturity } \\
\text { (Yrs.) }\end{array}$ & $\begin{array}{l}\text { Average } \\
\text { Offer Yield } \\
(\%)\end{array}$ \\
\hline 1987 & 62 & 118.2 & 4.79 & 8.15 \\
1988 & 65 & 129.94 & 6.92 & 7.96 \\
1989 & 42 & 149.58 & 3.64 & 9.40 \\
1990 & 31 & 110.55 & 4.13 & 9.12 \\
1991 & 24 & 113.85 & 4.08 & 8.35 \\
\hline
\end{tabular}

The U.S.-bond yields were obtained from the Analytical Record of Yield and Yield Spread by Solomon Brothers, Inc. The yields were monthly average yields on 10-year AAA and 10-year AA new industrials. Daily rates of return and Standard and Poor's Composite Index were obtained from the Center for Research in Security Prices (CRSP) daily data.

\section{METHODOLOGIES AND RESULTS}

\subsection{Comparison Of U.S.-Bond And Eurobond Announcement Effects On Firm Value}

An event study method that is based on the procedure used by (Aharony \& Swary, 1980) was applied to evaluate stock price reaction to the announcement of Eurobonds. The announcement day (day 0) is defined as the launch date, i.e. the first trading date of Eurobonds outside the United States. Abnormal returns were the residuals of the market model where its parameters were estimated by regressing the daily rate of return of a company on a constant and the daily rate of return on Standard and Poor's Composite Index (used as market return). The period used for estimating the parameters of the market model was day -110 to day -10 before the Eurobond 
announcement date. The average abnormal return (AAR) was computed for each day i from 10 days before to 10 days after the announcement of Eurobonds. The AAR is defined as:

$$
\operatorname{AAR}_{i}=\frac{1}{N_{c}} \sum_{j=1}^{N_{c}} \frac{1}{N_{a}} \sum_{k=1}^{N_{a}}\lceil j k i
$$

Where:

$$
\begin{aligned}
& N_{c}=\text { Number of companies } \\
& N_{a}=\text { Number of announcements for each company } \\
& j \mathrm{ki}=\text { Abnormal return for company } j, \text { announcement } k, \text { for day } i
\end{aligned}
$$

The result of the analysis indicates that the Eurobond announcement affects share prices positively two days after the announcement is made. The average abnormal return for day +2 is statistically significant at $1 \%$ level $(t=2.827)$, Table 2. Although we expected similar results for day $(0)$ and day $(+1)$, the average abnormal return for these two days were not statistically different from zero. The unexpected results for days $(0)$ and $(+1)$ may have been caused by a lag between the Eurobond launch date (first day of trading overseas) and the date the U.S. market is informed of issuing Eurobonds.

Table 2

Average Abnormal Returns for Ten Days Before and Ten Days After The Announcement of Eurobond Issues

\begin{tabular}{llr}
\hline Days Relative & Average Abnormal & t-Statistic \\
To Announcement Date & Return & -0.605 \\
\hline-10 & -0.000801089 & 1.272 \\
-9 & 0.001398211 & -0.033 \\
-8 & -0.00004413 & -0.731 \\
-7 & -0.001125485 & -0.311 \\
-6 & -0.000498057 & -0.598 \\
-5 & -0.000832089 & -0.247 \\
-4 & -0.000501534 & -1.040 \\
-3 & -0.001403469 & -0.249 \\
-2 & -0.000486535 & -0.249 \\
-1 & -0.000362912 & -0.255 \\
0 & -0.000279793 & 0.902 \\
+1 & 0.001192878 & $2.872^{*}$ \\
+2 & 0.004103281 & 1.039 \\
+3 & 0.001366527 & 0.592 \\
+4 & 0.001504953 & -0.634 \\
+6 & -0.000922691 & 0.976 \\
+7 & 0.001519384 & -1.271 \\
+8 & -0.001770664 & -1.481
\end{tabular}

To alleviate the possible problem of time disparity between the launch date overseas and the announcement date in the United States, window average abnormal return for days (0) to $(+2)$ was calculated. The results show that the window average abnormal return is statistically different from zero at $2 \%(t=2.39)$. These results confirm this paper's hypothesis and indicate that the straight Eurobond announcement has a positive impact on firm value in spite of the disappearance of Eurobond's tax advantage. The positive announcement effect of issuing Eurobonds 
also supports our statement that domestic and international capital markets continue to remain segmented. The privacy and portfolio diversification advantages of Eurobonds attract investors that cannot acquire these benefits by investing in U.S.-bond market.

\subsection{Analysis Of The Effects Of Eurobond Characteristics On Firm Value}

Further detailed analysis of the data was performed to determine which characteristics of Eurobonds influenced the increase in firm value. The factors considered were yield spread, issue size, frequency of issues, and maturity term.

Yield spread is the difference between the U.S.-bond yield and the company's Eurobond yield during the month of issue. The spread was calculated in two ways - using the monthly average yield on medium term AAA U.S.-bonds and using the monthly average yield on medium term AA domestic bonds. It was assumed that Eurobonds have the same level of risk as either AAA or AA rating U.S.-bonds.

Size is the principal amount of the issue. Frequency is the number of times a company has issued Eurobonds during the sample period. The frequency variable was represented by a dummy variable taking the value of 0 (zero) for low-frequency and 1 for high-frequency. On the average, a company issued Eurobonds four times during the sample period. Both size and frequency variables were used as proxies for measuring a firm's reputation. It was assumed that more reputable firms are able to sell larger issues of Eurobonds and enter the Eurobond market more frequently.

Most straight issues of Eurobonds have maturities of three, five, or ten years Mitchell (1991). However, U.S.-bonds' maturities can extend to 30 years. The maturity variable was used to determine if the shorter life of Eurobonds has any significance in explaining the abnormal returns.

A regression model with window average abnormal return as the dependent variable and the aforementioned four factors as the independent variables was used. Results of the regression analysis indicate that the coefficient of the spread variable is positive and statistically significant at approximately a 7\% level (Table 3). This result is consistent with the hypothesis that U.S. firms can take advantage of profitable opportunities in the Eurobond market. The coefficients of the other variables - issue size, frequency of issues, and maturity term were not statistically significant, indicating that these variables do not affect firm value.

\subsection{Analysis Of Eurobond Low And High Offering Frequency On Firm Value}

Further analysis was performed to determine the effect of a very low and very high frequency of issue of Eurobonds on firm value. Two sub-samples of the data were used for this study. The first sub-sample included 25 companies that made only a single announcement during the sample period. The second sub-sample consisted of 6 firms that made 107 launches. The firms in the second sub-sample were those companies that had entered the Eurobond market at least 9 times during the sample period. A regression model with window average abnormal return as the dependent variable and the aforementioned four factors as the independent variables was used to analyze each of the two sub-samples. 
Table 3

Regression Results for the Entire Sample

The dependent variable is window average abnormal return for days $(0)$ to $(+2)$ The privacy and portfolio diversification features of Eurobonds make them attractive to non-U.S. investors.

\section{Part A}

\begin{tabular}{llc} 
Independent variable $^{\mathbf{a}}$ & Coefficient & t-Statistic \\
\hline Intercept & 0.000582 & 0.323 \\
Frequency & -0.000778 & -0.657 \\
Size & 0.000000140 & 0.024 \\
Maturity & 0.000048988 & 0.185 \\
Spread (AAA) & 0.00039 & 1.801 \\
\hline
\end{tabular}

Notes:

a - The independent variables are defined as follows: Frequency is a dummy variable taking the value of 0 or 1 . Frequency is the number of times a company has issued Eurobonds during the sample period. The size variable is the principle amount of the issue. The maturity variable is the number of years from issue date until the date the Eurobond matures. The spread (AAA) variable is the difference between the monthly average yield on medium term AAA domestic bonds and the company's Eurobond yield during the month of issue.

\section{Part B}

\begin{tabular}{llc} 
Independent variable $^{\mathbf{b}}$ & Coefficient & t-Statistic \\
\hline Intercept & 0.000543 & 0.302 \\
Frequency & -0.000783 & -0.662 \\
Size & 0.000000101 & 0.017 \\
Maturity & 0.000044100 & 0.166 \\
Spread (AA) & 0.000400 & 1.846 \\
\hline
\end{tabular}

Notes:

b - The independent variables are defined as follows: Frequency, Size and Maturity are the same as in part a. Spread (AA) variable is the difference between the monthly average yield on medium term AA domestic bonds and the company's Eurobond yield during the month of issue.

The results of the regressions are presented in tables 4 and 5. The coefficient of the spread variable is significant at the $2 \%$ level only for the first sub-sample $(t=1.788)$. This result indicates that the positive effect of infrequent issue of Eurobonds on a firm's value is statistically significant. The spread variable is not significant for the high frequency sub-sample. Abnormal returns were calculated for the firms in the second sub-sample. The ttest results showed no statistically significant abnormal returns for the second sub-sample. This result indicates that the effect of frequent issues of Eurobonds on firm value is statistically insignificant. These results are consistent with Kim and Stulz (1988), who state that reputable firms can benefit more the first time they enter the Eurobond market.

However, as the results of the high frequency sub-sample indicate, the financing bargains disappear if firms enter the Eurobond market frequently. A plausible explanation for these results is that investors would be willing to accept the lower yield of the first issue of a Eurobond and invest in it to diversify their portfolios and reduce their overall portfolio risk. This effect disappears soon, and companies that frequently issue Eurobonds will be unable to significantly benefit from the lower yield because most investors have already included them in their portfolios. 
Table 4

Regression Results for the Low Frequency Sub-Sample

The low frequency sub-sample includes 25 companies that made a single Eurobond issue. The dependent variable is window average abnormal return for days $(0)$ to $(+2)$.

\begin{tabular}{llc} 
Independent variable $^{\mathbf{a}}$ & Coefficient & t-Statistic \\
\hline Intercept & 0.002259 & 0.323 \\
Size & 0.000005919 & 0.074 \\
Maturity & 0.000184 & 0.269 \\
Spread (AAA) & 0.001499 & 1.788 \\
\hline
\end{tabular}

Notes:

a - The independent variables are defined as follows: The size variable is the principle amount of the issue. The maturity variable is the number of years from issue date until the date the Eurobond matures. The spread (AAA) variable is the difference between the monthly average yield on medium term AAA domestic bonds and the company's Eurobond yield during the month of issue.

Table 5

Regression Results for the High Frequency Sub-Sample

The second sub-sample includes 6 companies that made at least 9 Eurobond issues during 1987-1991. The dependent variable is window average abnormal return for days 0 to +2 period. The sample uses 107 observations.

\begin{tabular}{lcc} 
Independent variable $^{\mathrm{a}}$ & Coefficient & t-statistic \\
\hline Intercept & -0.003260 & -0.519 \\
Size & 0.000003978 & 0.573 \\
Maturity & 0.000623 & 0.363 \\
Spread (AAA) & 0.000311 & 1.937 \\
\hline Notes: & \\
a - The independent variables are defined as follows: The size variable is the principle amount of the issue. The maturity \\
variable is the number of years from issue date until the date the Eurobond matures. The spread (AAA) variable is the difference \\
between the monthly average yield on medium term AAA domestic bonds and the company's Eurobond yield during the month \\
of issue.
\end{tabular}

\section{CONCLUSIONS}

This study showed that despite the disappearance of the Eurobond tax advantage, U.S.-bond and Eurobond markets remained segmented. The increase in firms' stock prices was significantly higher for issuing Eurobonds than U.S.-bonds. The privacy and portfolio diversification features of Eurobonds make them attractive to non-U.S. investors.

A more detailed analysis revealed that only firms that issued Eurobonds for the first time benefited from the Eurobond-related financing bargains. However, firms that entered the Eurobond market frequently did not earn any statistically significant value.

We conclude that firms that are new in the Eurobond market can benefit from the lower yield since there is demand for their new Eurobonds by investors who would want to diversify their portfolios. Investors include these issues in their portfolios to achieve diversification and risk reduction. As investors include the individual firms' Eurobonds in their portfolios, demand for these Eurobonds decreases and so does the financing bargains for the firms. 


\section{AUTHOR INFORMATION}

Roya K. Ardalan earned her PhD in Finance and is currently a member of the faculty in the College of Business and Public Administration at Old Dominion University. Her fields of interest are corporate finance and strategic use of information technology. She has published in the British Journal of Educational Technology, Industrial Management \& Data Systems, and proceedings of several major conferences.

\section{REFERENCES}

1. Adler, M., \& Dumas, B. (1983). International portfolio choice and corporation finance: A synthesis. Journal of Finance, Vol. 38, pp. 925-984.

2. Aharony, J., \& Swary, I. (1980). Quarterly dividend and earnings announcements and stockholders' returns: An empirical analysis. Journal of Finance, 35, 1-12.

3. Alexander, G., Eun, C. \& Janakiramanan, S. (1987). Asset pricing and dual listing of foreign capital markets: A note. Journal of Finance, 42, 151-158.

4. Alexander, G. (1988). International listings and stock returns: Some empirical evidence. Journal of Financial and Quantitative Analysis, 23, 135-151.

5. Amira, K. (2004). Determinants of sovereign Eurobond yield spread. Journal of Business Finance and Accounting, 31, 795-821.

6. Beer, F. (1995). The dollar Eurobond market. American Business Review, 13, 47-53.

7. $\quad$ Bowe, M. (1988). Eurobonds (Dow Jones-Irwin).

8. Deshpande, S., \& Philippatos, G. (1988). Leverage decisions and the effect of corporate Eurobond offerings. Applied Economics, 20, 901-915.

9. $\quad$ Eckbo, B. (1986). Valuation effect of corporate debt offerings. Journal of Financial Economics, 15, 119151.

10. Finnerty, J., \& Nunn, K. (1985). The determinants of yield spreads on U.S. and Eurobonds. Management International Review, 25, 23-33.

11. Kidwell, D., Marr, M., \& Thompson, G. (1985). Eurodollar bonds: Alternative financing for U.S. companies. Financial Management, Winter, 18-27.

12. Kim, Y., \& Stulz, R. (1988). The Eurobond market and corporate financial policy: A test of the clientele hypothesis. Journal of Financial Economics, 22, 189-205.

13. Kim, Y., \& Stulz, R. (1992). Is there a global market for convertible bonds? Journal of Business, 65, 75-91.

14. Mahajan, A., \& Fraser, D. (1986). Dollar Eurobond and U.S. bond pricing. Journal of International Business Studies, 17, 21-36.

15. Marr M., Trimble, J., \& Varma, R. (1991). On the integration of international capital markets: Evidence from Euroequity offerings. Financial Management, Winter, 11-21.

16. Mendelson, M. (1980). Money on the move. New York: McGraw-Hill.

17. Mendelson, M. (1983). The Eurobond and foreign bond markets. In A.M. George \& I. Giddy (Eds.), International finance handbook. New York: Wiley.

18. Mikkelson, W., \& Partch, M. (1986). Valuation effects of security offerings and the issuance process. Journal of Financial Economics, 15, 31-60.

19. Mitchell, J. (1991). Eurodollar bonds. Euromoney, November.

20. Murphy, A. (2003). An empirical analysis of the structure of credit risk premiums in the Eurobond market. Journal of International Money and Finance, 22, 865-885.

21. Stapleton, R., \& Subrahmanyam, M. (1977). Market imperfections, capital market equilibrium and corporation finance. Journal of Finance, 32, 307-319.

22. Steiner, M., \& Heinke, V. (2001). Event study concerning international bond price effects of credit rating actions. International Journal of Finance and Economics, 6, 139-157.

23. Stulz, R. (1981). On the effects of barriers to international investment. Journal of Finance, 36, 923-934. 